\title{
Mapping biomass and carbon stock of forest by remote sensing and GIS technology at Bach Ma National Park, Thua Thien Hue province
}

\author{
Xây dụng bản đồ sinh khối và trũ lượng carbon rùng bằng công nghệ viễn thám \\ và GIS tại vườn quốc gia Bạch Mã, tỉnh Thù̃a Thiên Huế \\ Research article
}

Nguyen, Hoang Khanh Linh*; Nguyen, Bich Ngoc

Faculty of Land Resource and Agricultural Environment, Hue University of Agriculture and Forestry, 102 Phung Hung, Hue City, Vietnam

The objective of this study is to build biomass and carbon stock map at several type of forest in Bach Ma National Park, Thua Thien Hue province. To accomplish that goal, field survey was accompanied with the interpretation result of remote satellite imagery in the GIS to determine biomass and carbon stock accumulation of forest. Landsat 8 satellite image year 2014 at 15 meters resolution was used for the analysis and classification of forest status. The results showed that the rich forest had the biggest amount biomass reserve in comparison with medium and restoration forest. It indicated that estimated biomass of rich forest was 144.16 tons/ha; meanwhile, biomass of medium and restoration forest was reached at 43.17 tons/ha and 20.31 tons/ha, respectively. It means that the total biomass of rich forest was approximately three times as the total biomass of medium forest and seven times compared to restoration forest. Based on estimated biomass map, carbon stock map at Bach Ma National Park was calculated. The carbon stock reserve of differential forest types was unequal and considerable disparity between the rich forest and the rest. Carbon stock of rich forest was 264.53 tons/ha, which was higher nearly three times than medium forest and nearly seven times than restoration forest. The determination of biomass and carbon stock map from tree layer not only contributes to understand the status of forest conditions, but also provide a strategy in reducing emissions and adaptation to climate change. In addition, the research results could be the scientific reference for trade sell carbon certificates in the commercial market within the country and globally.

Mưc tiêu của nghiên cứu này là xây dưng được bản đồ sinh khối và trũ luợng cacbon của tầng cây gố tại một số trạng thái rùng thuộc vuờn quốc gia Bạch Mã, tỉnh Thùa Thiên Huế. Để thực hiện được mục tiêu đó, nghiên cúu đã phối hợp kết quả phân loại ảnh với số liệu điều tra thực địa trong GIS để xác định sinh khối rùng, trũ lựng carbon tích lưy của tầng cây gố ở các trạng thái rùng thuộc vươn quốc gia Bạch Mã, tỉnh Thù̀a Thiên Huế. Anh vệ tinh landsat 8 năm 2014 có độ phân giải 15 mét được sử dụng để phân tích và phân loại hiện trạng rùng. Kết quả nghiên cứu cho thấy, trạng thái rùng giàu có sinh khối lớn hơn nhiều so với 2 trạng thái rùng còn lại, tổng sinh khối uoớc tính là144,16 tấn/ha. Sinh khối rùng trung bình đạt 43,17 tấn/ha, còn sinh khối rùng của rùng phục hồi là 20,31 tấn/ha. Tổng sinh khối rùng giàu xấp xỉ gấp 3 lần so với rùng trung bình và gấp 7 lần so với rùng phục hồi. Đối vói trũ lượng carbon của các trạng thái rùng không đồng đều nhau và có sụ chênh lệch khá lớn giũua rùng giàu và các trạng rùng còn lại. Trũ luợng carbon của rùng giàu là 264,53 tấn/ha cao hơn gần gấp 3 so với rù̀ng trung bình và gấp gần 7 lần so với rùng phuc hồi. Kết quả việc xác định sinh khối và trũ luợng carbon tầng cây gố của các trạng thái rùng cung cấp co sở khoa học và tạo điều kiện thuận lợi cho việc buôn bán chưng chỉ carbon trên thị trưòng thuong mại trong phạm vi quốc gia và toàn cầu.

Keywords: $\quad$ Bach $\mathrm{Ma}$, biomass, $\mathrm{CO}_{2}$ stock, forest, remote satellite 


\section{Introduction}

One of the problems being concerned of the world is the greenhouse gas emissions, especially $\mathrm{CO}_{2}$ from forest loss and forest degradation. Because forest is the place where stores more carbon than any ecosystem on Earth and has an important role in curbing climate change around the world. Tropical deforestation emissions were estimated from 1-2 billion tons of carbon each year (Fearnside P M, 2004; Houghton R Am 2005; Malhi Y, 2000). Deforestation and forest degradation were well known as the causes of greenhouse gas emissions in most of tropical countries (FAO, 2005). Therefore, manage $\mathrm{CO}_{2}$ (carbon dioxide) in natural forest is one of the most important challenge in reducing the influence of greenhouse gas emission to global climate. In fact, forest ecosystem, especially natural forest in the Bach Ma National Park plays an important role in the carbon cycle. Biomass is also an important indicator in the $\mathrm{CO}_{2}$ absorption. The recent research showed that $\mathrm{CO}_{2}$ mainly accumulated in biomass of the trees. The ability to absorb $\mathrm{CO}_{2}$ depends on the species of tree, trunk diameter, and yield of each forest status (Brown, S. 1997; Chave et al, 2005; Ketterrings et al, 2001). Therefore, the evaluation of forest, biomass, and carbon reserves is very necessary.

In recent years, various researches relating to determination of forest biomass were studied; whose results are the basis for the proposed economic estimation and carbon credits of forest yield. The standard method as creating and counting standard cell directly from the field was utilized (Vo Dai Hai, 2013; Bao Huy, 2011). This method has high precision, but it is expensive and takes a lot of time. In particular, it is difficult to apply in any far distant places and complex terrain conditions. In this case, remote sensing and GIS technology in combination with fieldwork investigation was implemented to determine carbon reserves of forest, which was considered as a new approach.

Study on biomass and carbon storage of forest not only give the strategy management and sustainable forest development but also contribute to the value of the environment, reduction of the gases causing the greenhouse effect and climate change in Vietnam and worldwide. Therefore, this article has studied the application of remote sensing and GIS technology to build biomass and carbon storage map of forest in Bach Ma National Park, in order to provide the scientific basis for forest carbon monitoring, increase the amount of Carbon reserves and sustainable forest management in REDD+ program and pay for environmental services of forests.

\section{Materials and methodologies}

\subsection{Overview of study site}

Bach Ma National Park is situated in Central Vietnam, $40 \mathrm{~km}$ southeast of the old imperial city of Hue. The park covers a total area of 37,487 ha $(34,380$ ha belong to Thua Thien Hue province and 3,107 ha belong to Quang Nam Province), within the latitude of $16^{\circ} 05^{\prime}-16^{\circ} 15^{\prime} \mathrm{N}$ and the longitude of $107^{\circ} 43^{\prime}-107^{\circ} 53^{\prime} \mathrm{E}$, which is managed with a minimum of human interference. The topography of the national park is generally steep and rugged, with several peaks above $1,000 \mathrm{~m}$, the highest of which is Mount Bach $\mathrm{Ma}$ at 1,448m (Thomas Geissmann, 2007). Bach Ma National Park is identified in Vietnam's Biodiversity Action Plan as one of the last remaining Type A primary forests which should receive the highest priority for protection due to its biodiversity value. The dominant habitats are tropical evergreen monsoon forest in the lower areas and subtropical evergreen monsoon forest at altitudes higher than $900 \mathrm{~m}$. The flora of Bach Ma includes at least 1,400 species. This represents around $19 \%$ of the entire flora of Vietnam in only 0.07 percent of Vietnam's total land area (Le Van Lan, 2002).

\subsection{Research methodologies}

\subsubsection{Surveying and collecting data}

Collecting current land use map, digital elevation model (DEM), the current forest resources through the year 2000, 2010, 2014 at the study area; Finding out the results of research in biomass and carbon stocks that had done before; Collecting report about the management and protection of forests at study site; acquisition Landsat 8 Images in Bach Ma National Park, taken in 2015.

\subsubsection{Determining the biomass with remote sensing}

- According to research by A. Schucknecht et al (2015) in the study "Biomass estimation to support pasture management in Niger", biomass was calculated from remote sensing by following formula [1].

$$
\mathrm{B}_{\mathrm{e}}=\mathrm{a} * \mathrm{fAPAR}+\mathrm{b}
$$

In which:

$\mathrm{B}_{\mathrm{e}}$ : estimated biomass from satellite imagery;

$a$ and $b$ : coefficients having from relationship between the actual biomass and fAPAR index in satellite imagery by linear regression function;

- fAPAR: component of solar radiation absorbed by plants through photosynthesis;

According to study of Ochi, S; Shibasaki, R (1999), fAPAR index is determined on the basis of the relationship with vegetation index (NDVI: normalized difference vegetation index), expressed by the following equation and this equation is generally applicable to countries in Southeast Asia

$$
\mathrm{fAPAR}=\mathrm{c}+\mathrm{d} * \mathrm{NDVI}
$$

In which:

$\mathrm{c}$ and $\mathrm{d}$ are empirical coefficients, determined for the Southeast Asian region $(\mathrm{c}=-0.08$ and $\mathrm{d}=1,075)$

\section{- The Normalized Difference Vegetation Index (NDVI)}

NDVI is used to demonstrate and monitor vegetation distribution at Bach Ma National Park. NDVI is calculated based on the difference reflectance near-infrared band (NIR) and red band of Landsat 8 as following formula:

$$
N D V I=\frac{N I R-R e d}{N I R+R e d}
$$

NDVI values range from +1.0 to -1.0 , but values less than zero typically do not have any ecological meaning, so the range of the index is truncated to 0.0 to +1.0 . Areas of bar- 
ren rock, sand usually show very low NDVI values (for example, 0.1 or less). Sparse vegetation such as shrubs and grasslands or senescing crops may result in moderate NDVI values (approximately 0.2 to 0.5 ). High NDVI values (approximately 0.6 to 0.9 ) correspond to dense vegetation such as that found in temperate and tropical forests or crops at their peak growth stage.

\section{- $\quad$ The Leaf area index (LAI)}

Leaf area index (LAI) is the ratio of upper leaf surface area to ground area (for broadleaf canopies), or projected conifer needle surface area to ground area (for coniferous plants) for a given unit area (Serrano et al, 2000). LAI could be used to estimate the biomass, dynamics of vegetation or crop forecast (Spanner et al, 1994). LAI value ranges from 0 to 6 or more. LAI value of 1 means that there is the equivalent of 1 layer of leaves that entirely cover a unit of ground surface area, and less than one means that there is some bare ground between vegetated patches. LAI values over 1 indicate a layered canopy with multiple layers of leaves per unit ground surface area. LAI can be generated from satellite images by using linear regression approach, which attempts to relate reflectance data recorded by a sensor to field measurements of LAI. Such approach may correlate field-measured fractional cover with sensor reflectance bands, or to vegetation indices like NDVI (Law \& Waring, 1994) as the following equation:

$$
\mathrm{LAI}=\mathrm{e}+\mathrm{f} * \mathrm{NDVI}
$$

Where: e and f are coefficients which will be calculated by analyzing the relationship between NDVI and LAI in reality.

\subsubsection{Identifying carbon stock}

According to IPCC (2003), Carbon stock will be measured by default coefficient with dried biomass:

$$
C B S=0.5 * T A B
$$

Where: CBS: Carbon stock; TAB: Total Biomass

$$
\mathrm{TAB}=\mathrm{AGB}+\mathrm{BGB}
$$

In which, AGB is aboveground biomass and BGB is belowground biomass. However, as discussed in the scope of the research, the study just focuses on only above-ground biomass. Therefore, the amount of carbon and $\mathrm{CO}_{2}$ will be calculated as formula:

$$
\begin{aligned}
& \mathrm{CBS}=0.5 * \mathrm{AGB}(7) \\
& \mathrm{CO}_{2}=3.67 * \mathrm{CBS}(8)
\end{aligned}
$$

\subsubsection{Interpretation satellite image}

Remote satellite image Landsat 8 was free downloaded from the website of United States Geological Survey (USGS) http://earthexplorer.usgs.gov, acquired in 2014. After reviewing, image LC81240512014030LGN00 with resolution of $30 \mathrm{~m} \times 30 \mathrm{~m}$, and cloud cover $3 \%$ was selected. ENVI 5.0 software was used for processing and interpretation Landsat 8 image for the study area. ArcGis10.2 was used for mapping forest land use as well as calculating biomass, and carbon reserves in the study area for each different forest condition.

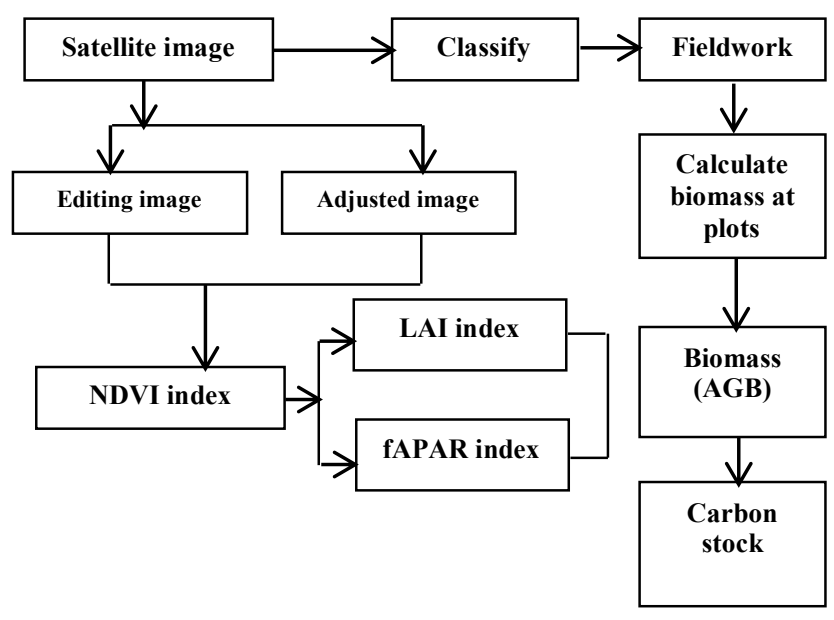

Figure 1. Framework for calculating biomass from forest canopy surface in satellite image

\subsubsection{Analyzing and processing survey data}

Linear regression in SPSS 20 software was used to analyze the relationship between NDVI on the photo and actual LAI index. In which, NDVI is the independent variable and LAI is the dependent variable, as formula:

$$
y=a x+b
$$

In addition, Pearson correlation coefficient was identified for two variables $\mathrm{x}$, $\mathrm{y}$ from the $\mathrm{n}$ samples, as the formula:

$$
r=\frac{\sum_{i=1}^{n}\left(x_{i}-\bar{x}\right)\left(y_{i}-\bar{y}\right)}{\sqrt{\sum_{i=1}^{n}\left(x_{i}-\bar{x}\right)^{2} \sum_{i=1}^{n}\left(y_{i}-\bar{y}\right)^{2}}}
$$

In particular, $\bar{x}$ and $\bar{y}$ is the medium value of the variables $x$ and $y$. If the value of $r$ is positive $(r>0)$, the two variables $x$ and $y$ has the same variation in one direction; if the value of $r$ is negative $(r<0), \mathrm{x}$ and $\mathrm{y}$ are reversed, ie.when $x$ increases, $y$ decreases. If $r=1$ or $r=-1$, the relationship of $x$ and $y$ are determined; which means that for any value of $x$, we can determine the value of $y$. If $r=0$, the two variables $x$ and $y$ are completely independent, have no relation with each other. The $r$ value is categorized as follows: $0.1 \leq$ $r<0.3$ low correlation, $0.3 \leq r<0.5$ medium correlation, $r \leq$ 0.5 high correlation.

\section{Results and discussions}

\subsection{Mapping forest cover}

Because the resolution of used image in the study is $30 \times 30 \mathrm{~m}$, it is needed to improve the resolution of the Landsat 8 for easy interpretation. In this case, panchromatic channel (15m resolution) was combined with other channels to create higher resolution imagery at $15 \times 15 \mathrm{~m}$. Then, the imagery was cut as border of Bach Ma National Park From and classified as rich forest, medium forest, restora- 
tion forest, water surface and other land under the combination of 3 channels respectively $5,4,3$. Within the scope of the subject, 31 standard cells range in various type of forest in field were surveyed to calculate the canopy. The location of these cells was identified by GPS device and could be found in Figure 2.

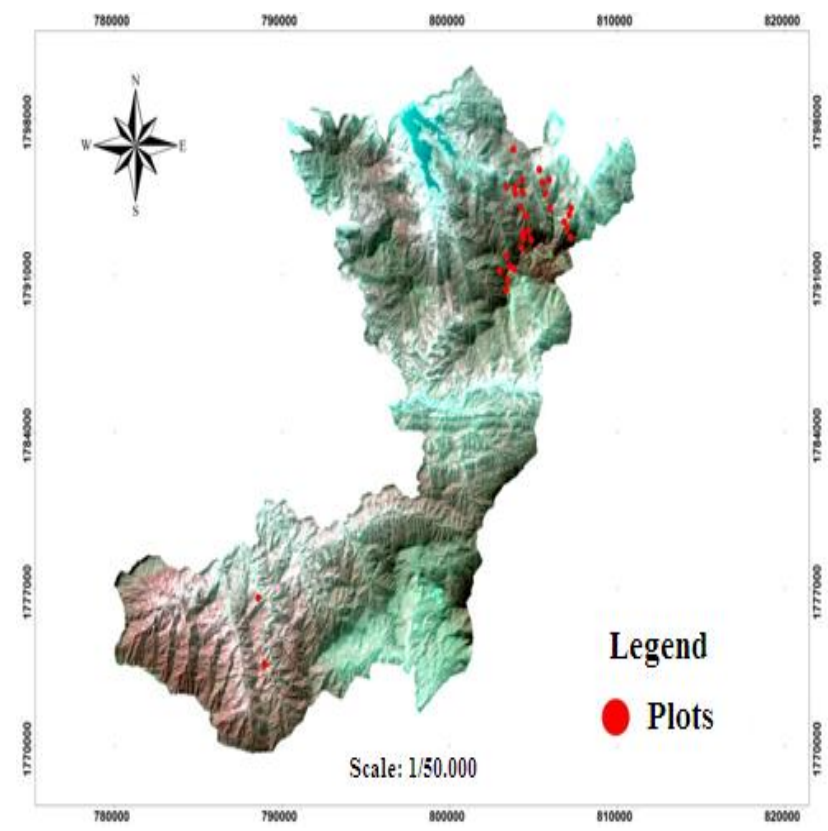

Figure 2. Location standard plots in the field

The result showed that the overall accuracy and Kappa index of image interpretation were pretty high, reached at $89.43 \%$ and 0.87 , respectively. According to LandisandKoch (1977), characterized the agreement of comparison between classified map and reference data as follows: values from 0.4 to 0.75 are fair to good, and values over 0.75 are good to excellent. Based on these criterions, LULC maps derived from remote satellite imagery can be used for further studying. Figure 3 shows that rich forest areas covered mainly in the southeast and northeast at around 7543 hectares $(20 \%$ of total area), while the medium forest and recovery forest were distributed across the territory with an area of 14,218 hectares (37.6\% of total area) and 12,830 (34\% of total area) hectares, respectively.

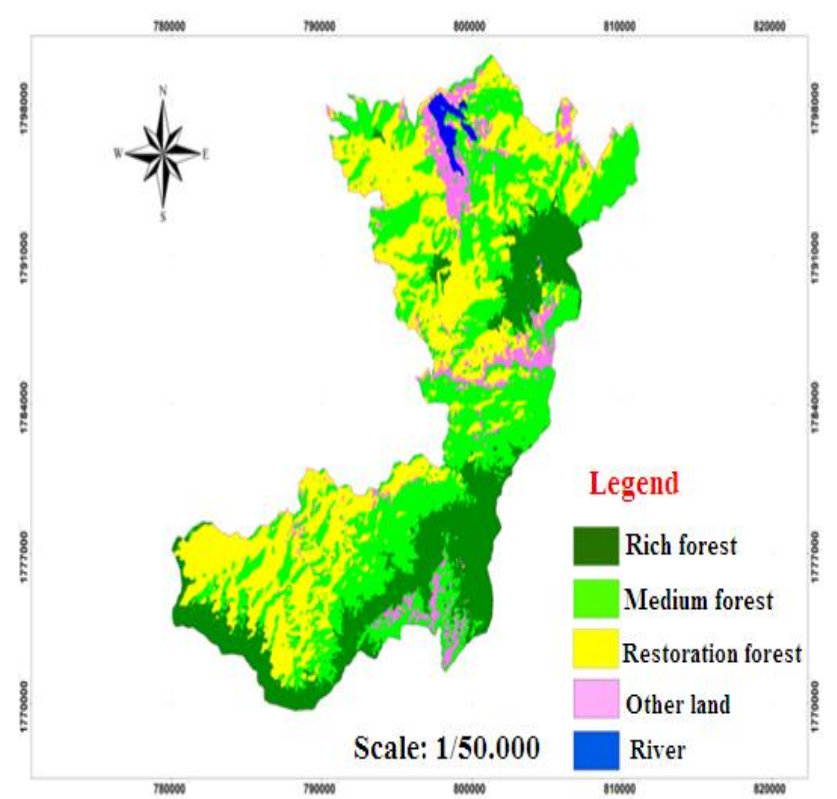

Figure 3. Map of vegetation cover at Bach Ma National Park

\subsection{Extracting main indices from remotely sensed imagery for calculating biomass}

\subsubsection{The Normalized Difference Vegetation Index (NDVI)}

The vegetation index NDVI was calculated by using the Transform tool in ENVI software. The result showed that average value of NDVI index in Bach Ma National Park was rather high (mean NDVI $=0.62$ ), in which, NDVI value of the forest status ranges from 0.5 to 0.7 . The finding is totally reasonable because of strictly conservation in national park. Therefore, trees could grow in good conditions which leads high NDVI values.

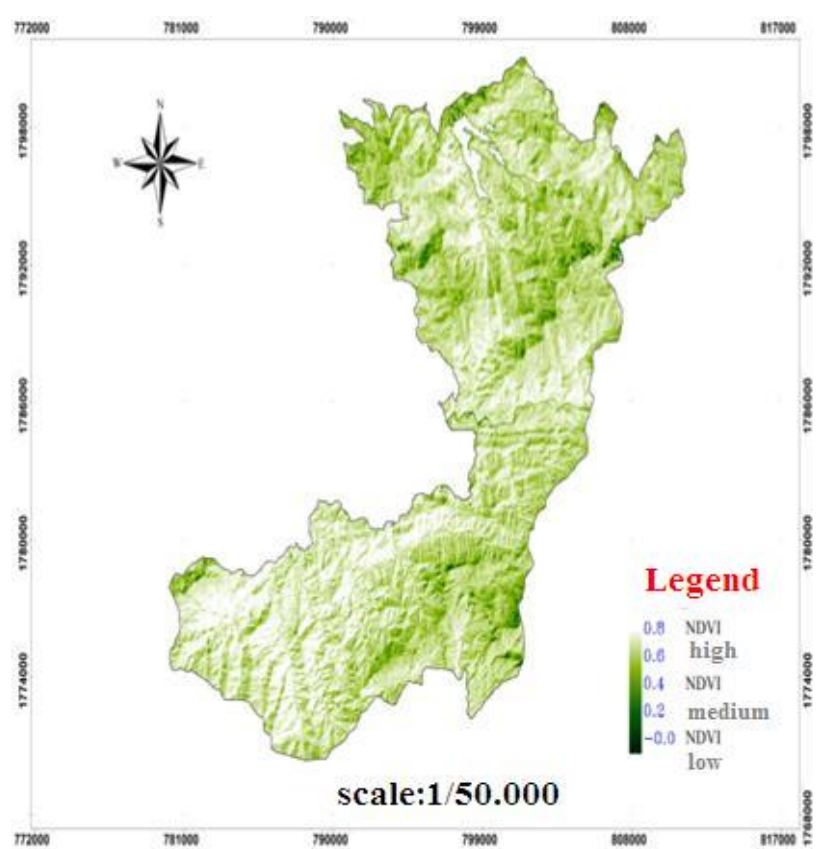

Figure 4. NDVI index of Bach Ma National Park

Based on research of Bui Nguyen Lam Ha et. al (2011), NDV value of natural forest or perennial plants fluctuates from 0.5 to 0.8. Comparing with determined NDVI values from Remote sensing imagery in Bach Ma National Park, the index is quite similar (Le Van Trung, 2011).

\subsubsection{The Leaf area index (LAI)}

After defining actual LAI index at each standard box in the field, LAI map was interpreted from satellite image by relationship between NDVI and LAI as formula (4) by linear regression analysis: LAI $=61.539-19.772 *$ NDVI with $\mathrm{R}^{2}=0.036$. The results showed that LAI index got from sample plots in the field and satellite image has the same average value (49.19\% and $47.84 \%$, respectively), with mean squared error around $6.1 \%$ and standard error approximately $15.55 \%$. It means that calculated biomass has accuracy at $84.45 \%$. The results got from remote satellite image are quite similar to the achieved results of field surveys. Results of statistical analysis showed that the average value of LAI index in image is 4.8 , which means that $1 \mathrm{~m}^{2}$ 
of ground is covered by 4,8 unit leaf surface. The maximum value of obtained LAI index in image is 6 and the minimum value is 0 . The smallest LAI value was defined as the location of the lake and vacant land, whereas the areas covered by dense vegetation with large biomass got high value of LAI index.

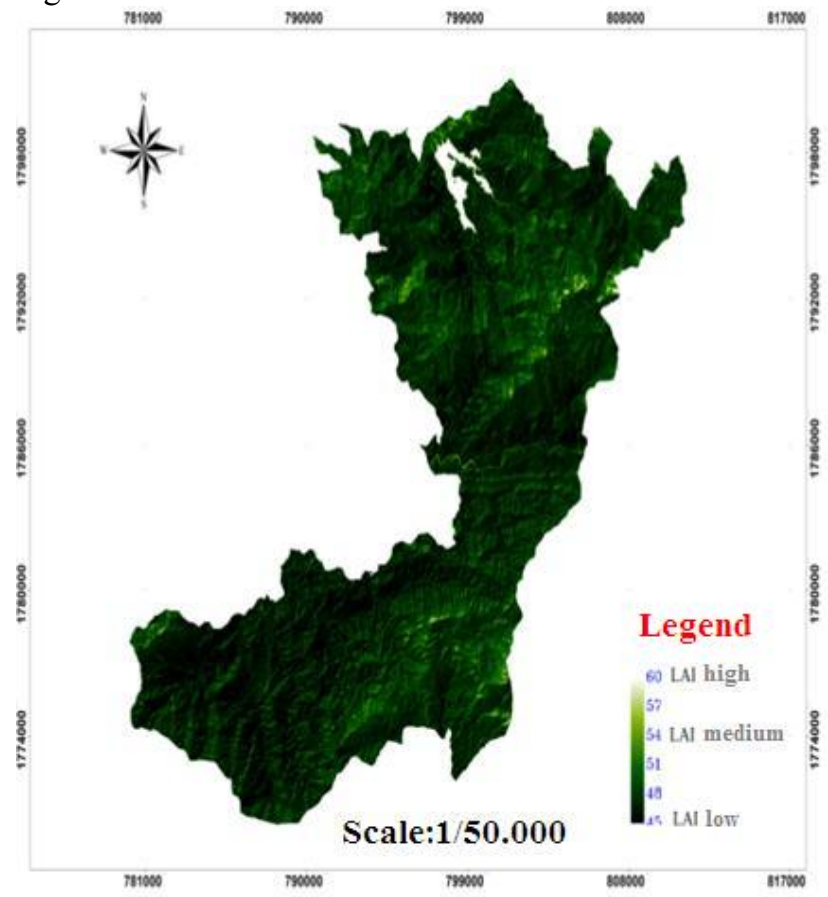

Figure 5. LAI index of Bach Ma National Park

According to Ha Bui Nguyen Lam et al (2011), LAI value of natural forest and perennial plants ranges from 4.5 to 6 [14]. In this case, the finding result was reasonable. More details about relationship between NDVI and LAI index at sample plots could be found at Figure 6. As can be seen, NDVI and LAI index has a positive correlation with $\mathrm{R}^{2}=$ 0.179 . It means that the more trees there are, the more biomass get.

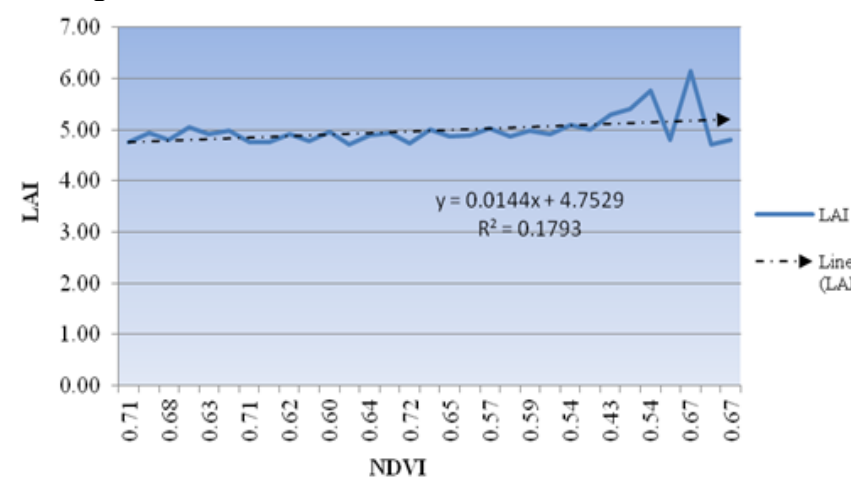

Figure 6. The correlation between NDVI and LAI

\subsubsection{The Fraction of Absorbed Photosynthetically Ac-} tive Radiation (fAPAR)

After determining NDVI for Landsat 8, fAPAR index was calculated based on formula 2 as ENVI Band Math equation: fAPAR $=-0.08+1.075 *$ NDVI. From then, fAPAR map was stablished for Bach Ma National Park (Figure 7).

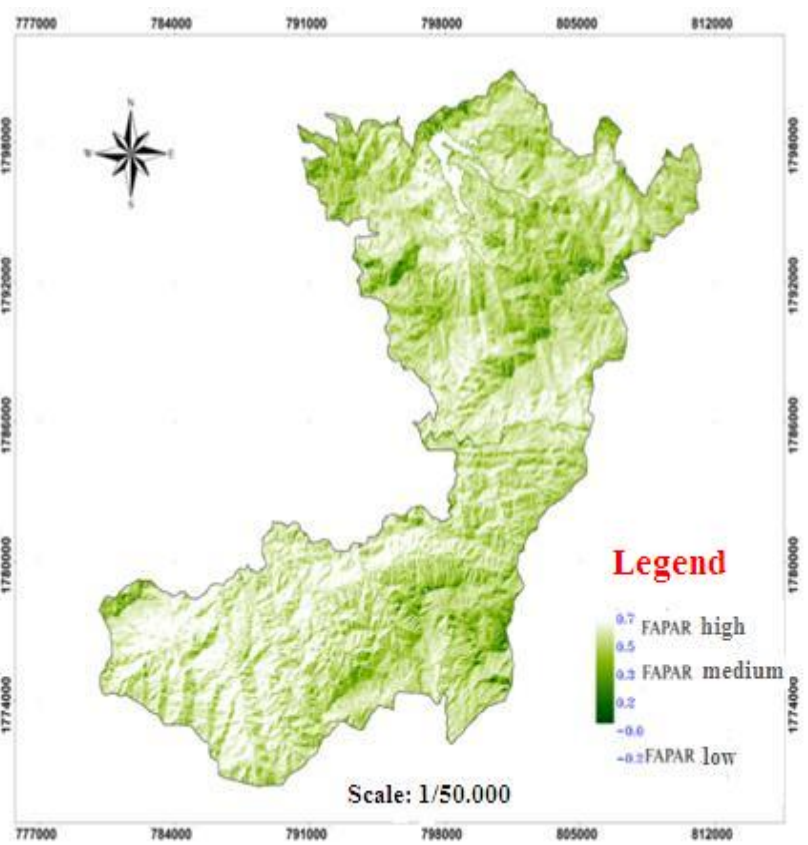

Figure 7. Distribution of fAPAR at study site

\subsection{Mapping forest biomass and carbon re- serves from remote sensing}

\subsubsection{Identifying biomass and carbon stock in different forest status}

\section{a. Rich forest}

11 circular plots were surveyed in the rich forest including 9 lots in Phu Loc district and 2 plots in Nam Dong district in Thua Thien Hue province (table 1). The result showed that biomass in most of the plots was very high with an average of 144.16 ton/ ha and 264.53 ton $\mathrm{CO}_{2}$ stock/ ha. However, there was a significant distinction of biomass among plots such as 377.38 ton/ha in plot 24 , whereas only $14.63 \mathrm{ton} /$ ha in plot 21 .

Table 1. Biomass of plots in rich forest

\begin{tabular}{|c|c|c|c|c|}
\hline \multirow{2}{*}{ Plots } & \multicolumn{2}{|c|}{ Coordinates } & \multirow{2}{*}{ Biomass (ton/ha) } & \multirow{2}{*}{$\begin{array}{c}\mathrm{CO}_{2} \text { stock } \\
\text { (ton/ha) }\end{array}$} \\
\hline & $\mathbf{X}$ & $\mathbf{Y}$ & & \\
\hline 16 & 805184 & 1795501 & 168.75 & 309.66 \\
\hline 17 & 805498 & 1795135 & 48.08 & 88.23 \\
\hline 18 & 805761 & 1794080 & 48.53 & 89.05 \\
\hline 19 & 805610 & 1794494 & 54.19 & 99.44 \\
\hline 21 & 805217 & 1793711 & 14.63 & 26.85 \\
\hline 23 & 804285 & 1793378 & 58.90 & 108.08 \\
\hline 24 & 803888 & 1792698 & 377.38 & 692.49 \\
\hline
\end{tabular}




\begin{tabular}{rrccc}
25 & 804479 & 1792882 & 347.06 & 636.86 \\
26 & 804780 & 1792756 & 77.12 & 141.52 \\
27 & 804369 & 1792285 & 174.29 & 319.82 \\
31 & 789885 & 1775100 & 216.84 & 397.90 \\
\hline & Average & $\mathbf{1 4 4 . 1 6}$ & $\mathbf{2 6 4 . 5 3}$
\end{tabular}

\section{b. Medium forest}

10 circular plots were designed in medium forest belonging to Phu Loc district - Thua Thien Hue province (table 2). The result showed that biomass and $\mathrm{CO}_{2}$ stock among plots were quite equal and fluctuated from 14.17 (plot 9) to 69.33 (plot
6) ton/ ha and 26 to 127.22 ton/ ha, respectively. It can be clearly seen that biomass of plots in the medium forest is absolutely low in comparison to the rich forest.

Table 2. Biomass of plots in medium forest

\begin{tabular}{|c|c|c|c|c|}
\hline \multirow{2}{*}{ Plots } & \multicolumn{2}{|c|}{ Coordinates } & \multirow{2}{*}{ Biomass (ton/ha) } & \multirow{2}{*}{$\begin{array}{c}\mathrm{CO}_{2} \text { stock } \\
\text { (ton/ha) }\end{array}$} \\
\hline & $\mathbf{X}$ & $\mathbf{Y}$ & & \\
\hline 2 & 808162 & 1795485 & 19.32 & 35.45 \\
\hline 4 & 808044 & 1795198 & 30.87 & 56.65 \\
\hline 6 & 806876 & 1795479 & 69.33 & 127.22 \\
\hline 7 & 807744 & 1794877 & 48.16 & 88.37 \\
\hline 8 & 807926 & 1794587 & 55.46 & 101.77 \\
\hline 9 & 808119 & 1794207 & 14.17 & 26.00 \\
\hline 13 & 804825 & 1796450 & 47.69 & 87.51 \\
\hline 14 & 804301 & 1796441 & 65.00 & 119.28 \\
\hline 15 & 804814 & 1796128 & 65.00 & 119.28 \\
\hline 22 & 805285 & 1794372 & 16.66 & 30.57 \\
\hline & & & 43.17 & 79.21 \\
\hline
\end{tabular}

\section{c. Restoration forest}

10 circular plots were researched in restoration forest in Phu Loc district, Thua Thien Hue province (Table 3). In general, biomass in this type of forest is very low with an average of 20.31 ton/ ha and 37.27 ton $\mathrm{CO}_{2}$ stock/ ha. The highest biomass concentrated in plot 20 (57.34 ton/ ha) and the lowest biomass in plot 11 with only 1.95 ton/ ha.

Table 3. Biomass of plots in restoration forest

\begin{tabular}{|c|c|c|c|c|}
\hline \multirow{2}{*}{ Plots } & \multicolumn{2}{|c|}{ Coordinates } & \multirow{2}{*}{ Biomass (ton/ha) } & \multirow{2}{*}{$\begin{array}{c}\mathrm{CO}_{2} \text { stock } \\
\text { (ton/ha) }\end{array}$} \\
\hline & $\mathbf{X}$ & $Y$ & & \\
\hline 1 & 806843 & 1796751 & 12.48 & 22.90 \\
\hline 3 & 806447 & 1796632 & 13.39 & 24.57 \\
\hline 5 & 806619 & 1796143 & 28.03 & 51.44 \\
\hline 10 & 806264 & 1797212 & 32.43 & 59.51 \\
\hline 11 & 805234 & 1796758 & 1.95 & 3.58 \\
\hline 12 & 805231 & 1796230 & 12.14 & 22.28 \\
\hline 20 & 805311 & 1794159 & 57.34 & 105.22 \\
\hline 28 & 804298 & 1791843 & 24.66 & 45.25 \\
\hline 29 & 804712 & 1798124 & 16.30 & 29.91 \\
\hline 30 & 789494 & 1778084 & 4.41 & 8.09 \\
\hline & & & 20.31 & 37.27 \\
\hline
\end{tabular}

\subsubsection{Establish biomass equation on Remote Sensing}

Biomass map was established from satellite image by formula (1) in the research methods based on the relationship between biomass value obtained from standard cell in the field and fAPAR indicator from plots on satellite image. After acquiring the biomass equation on the image associated with the Band Math tools in the ENVI software, we achieved decentralization map of forest biomass in Bach Ma National Park as the following figure. 


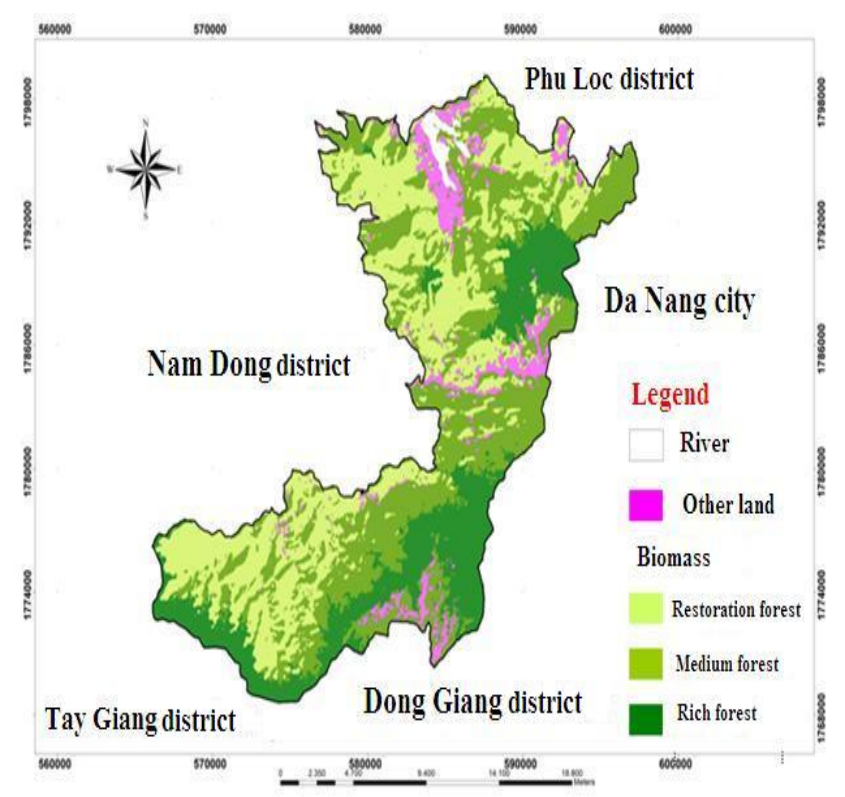

Figure 8. Decentralized map of forest biomass

\subsubsection{Mapping Carbon stock}

Based on forest biomass map, the carbon map of different forest types at Bach Ma National Park were identified by formula (7).

Table 4. Carbon Market value of different forest types

\begin{tabular}{ccccc} 
Forest type & Area (ha) & $\mathbf{C O}_{\mathbf{2}}$ (tons/ha) & Unit (USD) & Evaluation of CO (USD) $^{\text {(USD }}$ \\
\hline Rich & 7543 & 264.53 & 5 & 9976748.95 \\
Medium & 14218 & 79.21 & 5 & 5631038.90 \\
Recovery & 12830 & 37.27 & 5 & 2390807.50 \\
\hline \multicolumn{2}{c}{ Sum } &
\end{tabular}

Basing on Table 4, it can be clearly seen that similar to biomass and carbon stock, the $\mathrm{CO}_{2}$ absorption ability of rich forest predominanted absolutely in comparison with two remaining other forest status. The medium forest had high $\mathrm{CO}_{2}$ absorption ability, yet it was still limited compare to rich forest. Meanwhile, although restoration forest had lowest $\mathrm{CO}_{2}$ stock, it has high potential in $\mathrm{CO}_{2}$ absorption in the near future with suitable protection and technique. It means that the National Park must have strategy to preserve and protect the forest resource, especially the rich and medium forest for the next years. In addition, the carbon market could give

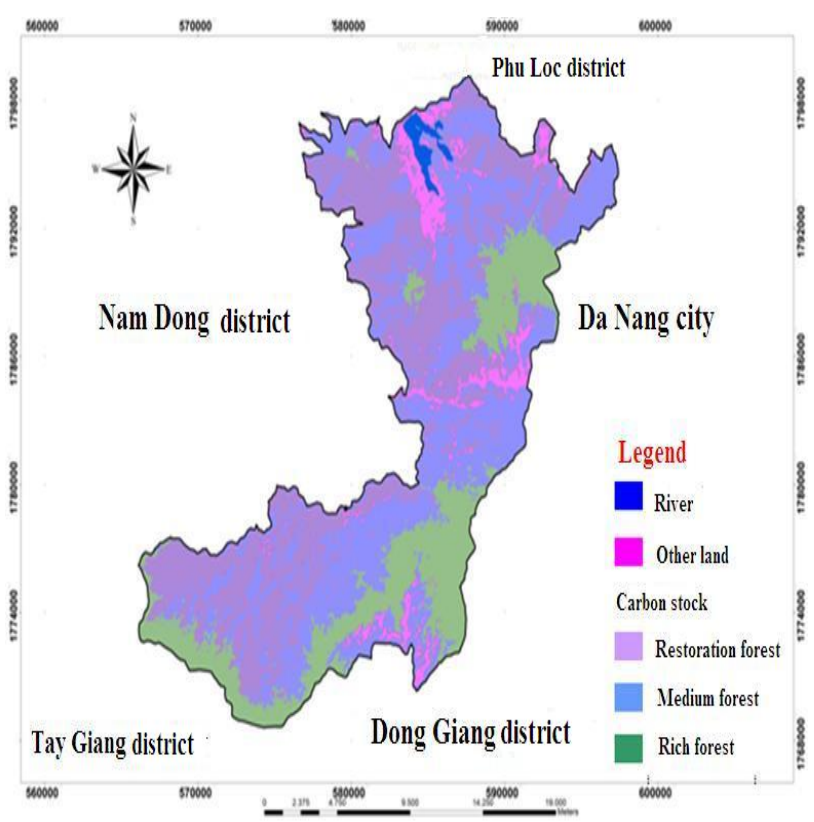

Figure 9. Carbon map of different forest types at Bach Ma National Park in 2015

\subsection{Estimating economic efficiency of carbon stocks in Bach Ma National Park}

Based on carbon map of different forest types at Bach Ma National Park, the analytical results showed that rich forest has highest amount of carbon $(264,5$ tons/ha), whereas medium and recovery forest has lower amount of carbon 79.2 tons/ha and 37.3 tons/ha, respectively. The finding results of this article demonstrate the similarities in research of the authors Duong Viet Tinh and Nguyen Thai Dung (2012) on the topic "Research CO2 fixation capacity of some state forest park Bach Ma" [13].

The efficiency of environmental services from carbon reserves of different forest types at Bach Ma National Park could be calculated. According to Forest Inventory and Planning Institute, Natural Resources and Environment Policy, if price of 1 ton $\mathrm{CO}_{2} /$ hectare in cash is $5 \$$, thus the total amount of payments for environmental services carbon is calculated as: Total payments $=$ amount of $\mathrm{CO}_{2} *$ Unit price (USD / ton $\mathrm{CO}_{2}$ ).

the National Park a potential resource to develop the park, particularly, the development of forest ecosystems there.

\section{Conclusions}

The integration of remote satellite and field survey in GIS technology is a new approach for the study of biomass and carbon stocks on above-ground layer of forest status. Estimated biomass, carbon accumulation in forest cover is quite good, which can be used as a reference for nature- 
oriented management on and is an important basis for determining the price of $\mathrm{CO}_{2}$ of each forest type for carbon commercial market within the country and globally.

Forest area in Bach Ma National Park is divided as: rich forest, medium forest and recovery forest. Rich forest distributed as large areas and located mainly in southeast and northeast of the park (7545ha). The medium and recovery forest is widely distributed throughout the region (14218ha; 12830ha, respectively). Depending on different type of forest, carbon stocks in Bach Ma National Park could be estimated through calculating from the biomass of forest conditions. Thus, application of remote sensing Landsat 8 in mapping biomass and forest carbon stocks in Bach Ma National Park has helped to clarify the theoretical basis of the calculation biomass in satellite image as well as experimental methods of mapping carbon stocks. The results could propose effective solutions for monitoring and managing carbon stocks.

\section{References}

[1] A Schucknecht, M. Meroni, F. Kayitakire, F. Rembold, A. Boureima (2015) "Biomass estimation to support pasture management in Niger".

[2] Forest Management Board (2014), Report on forest management and protection of Bach Ma National Park.

[3] Brown, S. (1997) "Estimating biomass and biomass change of tropical forests: a Primer. FAO Forestrypaper-134. ISBN92-5-103955-0.

[4] Chaveetal (2005), Tree allometry and improved estimation of carbon stocks and balance in tropical forests. Oecologia, 145:87-99.

[5] Duong Viet Tinh and Nguyen Thai Dung (2012), The ability of fixed $\mathrm{CO}_{2}$ in forest status of Bach Ma National Park, Nam Dong district, Thua Thien Hue province, Report in 2012.

[6] FAO (Food and Agricultural Organization of the United Nations), (2005) FAO Statistical data base 2005 available at http:// faostat.fao.org/ (accessed 2005-09-06).

[7] Fearnside P M and Laurance W F. (2004) Tropical deforestation and greenhouse gas emissions Ecological Appl. 14, 982 - 986.

[8] Houghton R A (2005). Tropical deforestation as a source of greenhouse gas emissions Tropical Deforestation and Climate Change, ed. Mutinho and
Schwartzman (Belem: IPAM).

[9] IPCC (2003), Good practice guidance for land uses, land use change and forestry. IPCC National Greenhouse Gas Inventories Programme.

[10] Ketteringsetal (2001), Reducing uncertainty in the use of allometric biomass equations for predicting above-ground tree biomass in mixed secondary forests, Forest Ecology and Management Journal, (120):199-209.

[11] Landis, J. R., and Koch, G. G., 1977, The Measurement of Observer Agreement for Categorical Data: Biometrics, v. 33, p. 159-174.

[12] Law, B.E. and R.H. Waring. (1994). Remote sensing of leaf area index and radiation intercepted by understory vegetation. Ecological Applications 42: 272279.

[13] Le Van Lan, S. Ziegler, T. Grever, (2002), Utilization of forest products and environmental services in Bach Ma National Park, Vietnam. Available online at www.mekong-protectedaeas.org/vietnam/docs/bach_ma_forest_products.pdf

[14] Le Van Trung, Bui Nguyen Lam Ha (2011), "Estimates of biomass on the surface of the forest canopy using ALOS satellite image AVNIR-2". Report on the subject.

[15] Malhi Y and Grace J (2000). Tropical forests and atmospheric carbon dioxide Trends Ecol. Evolut. 15, p. 332-7.

[16] Ochi, S.; Shibasaki, R (1999), Assessment of primary productivity for food production in major basins of Asia using R.S and GIS.

[17] Serranoetal. (2000), Remote Sensing of Biomass and Yield of Winter Wheat under Different Nitrogen Supplies".

[18] Spanneretal. (1994), "National- Scale Biomass Estimators for United States Tree Species".

[19] Thomas Geissmann, Trinh Dinh Hoang, La Quang Trung, Lucy Tallents, (2007), A brief survey for crested gibbons in Bach Ma National Park, central Vietnam, Gibbon Journal Nr.3

[20] Vo Dai Hai, Dang Thinh Trieu (2013), Studying CO2 absorption capacity of natural forests broadleaf evergreen, semi-evergreen deciduous Highlands, Report research project. 